\title{
Pain, Quality of Life, and Clinical Outcomes after Robotic Lobectomy
}

\author{
Valerie Lacroix ${ }^{1}$ Zahra Mosala Nezhad ${ }^{1}$ David Kahn ${ }^{2}$ Arnaud Steyaert ${ }^{2}$ Alain Poncelet ${ }^{1}$
}

Thierry Pieters $^{3}$ Philippe Noirhomme ${ }^{1}$
${ }^{1}$ Department of Cardiovascular and Thoracic Surgery, IREC, Cliniques Universitaires Saint Luc, Bruxelles, Belgium
2 Department of Cardiac Anesthesia, Cliniques Universitaires Saint Luc, Bruxelles, Belgium
${ }^{3}$ Division of Pulmonary Medicine, Cliniques Universitaires Saint Luc, Bruxelles, Belgium

Thorac Cardiovasc Surg 2017;65:e1.
Address for correspondence Valerie Lacroix, MD, PhD, Department of Cardiovascular and Thoracic, Cliniques Universitaires Saint Luc, Avenue Hippocrate 10, Bruxelles 1200, Belgium (e-mail: valerie.lacroix@uclouvain.be).

\section{ERRATUM}

It has been brought to the Publisher's attention that the author's family name "Zahra Mosala Nezhad" was not tagged correctly in the above-mentioned article, published on eFirst on August 30, 2016. DOI of the original article is DOI: 10.1055/s-0036-1587590. The names should be listed with "Zahra" as first name and "Mosala Nezhad" as family name. 